\title{
Choice of Levels in Selective Neck Dissection and Its Impact On Regional Control and Survival in 661 Patients With Head and Neck Squamous Cell Carcinoma
}

\section{Mattis Bertlich}

University Hospital, Ludwig-Maximilians-University of Munich

Nina Zeller

Klinikum Frankfurt Höchst

\section{Saskia Freytag}

Harry Perkins Institute of Medical Research

\section{Bernhard G. Weiss}

University Hospital, Ludwig-Maximilians-University of Munich

\section{Martin Canis}

University Hospital, Ludwig-Maximilians-University of Munich

\section{Frank Haubner}

University Hospital, Ludwig-Maximilians-University of Munich

Friedrich Ihler ( $\square$ Friedrich.Ihler@med.uni-muenchen.de )

University Hospital, Ludwig-Maximilians-University of Munich

Jennifer L. Spiegel

University Hospital, Ludwig-Maximilians-University of Munich

\section{Research Article}

Keywords: Selective Neck Dissection, Head \& Neck Squamous Cell Carcinoma

Posted Date: September 13th, 2021

DOl: https://doi.org/10.21203/rs.3.rs-667635/v1

License: (c) (1) This work is licensed under a Creative Commons Attribution 4.0 International License. Read Full License 


\section{Abstract}

Background: Selective Neck Dissection (SND) is the surgical treatment of choice in suspected or manifest nodal positive squamous cell carcinoma of the head and neck (HNSCC). For SND to be successful, treated levels should be selected accordingly. Aim of this study was to identify neck dissection levels that had an impact on the individual prognosis.

Methods: We conducted a retrospective review of SND as part of primary treatment of HNSCC. Overall survival (OS) and regional control rates (RCR) were calculated for all patients.

Results: 661 patients with HNSCC were included, 644 underwent ipsilateral and 319 contralateral SND. Average follow up was $78.9 \pm 106.4$ months. 67 (10.1\%) patients eventually developed nodal recurrence. Tumor sites were oral cavity (135), oropharynx (179), hypopharynx (118) and larynx (229). Tumor categories pT1 - pT4a, and all clinical and pathological nodal categories were included. Multivariate analysis indicated improved OS rates for patients undergoing SND in ipsilateral levels I and V as well as level III contralaterally. Analysis for tumor origin showed that SND in ipsilateral level I showed a significantly improved OS in HNSCC of the oral cavity.

Conclusion: In HNSCC of the oral cavity, ipsilateral level I needs to be included when performing SND.

\section{Introduction}

Clinical and pathological presence of lymph node metastasis is - apart from distant metastasis - the most important prognostic factor in patients suffering from squamous cell carcinoma of the head and neck (HNSCC).(1) It has been reported that only one affected lymph node may decrease overall survival rates by as much as $50 \%$.(2) Consequently, adequate treatment of the lymphatic regions is paramount to obtain an adequate oncologic result.

Generally speaking, the neck is commonly treated in the same manner as the primary tumor - i.e. if the tumor was treated surgically, so is the neck, with or without postoperative radio-(chemo-)therapy. In turn, if a tumor is treated by definitive chemoradiation, the neck is commonly radiated as well. If the neck is treated surgically, selective neck dissection (SND) is the treatment of choice,(3) except in cases where non-lymphatic structures are involved by tumor spread and have to be removed by radical or modified radical neck dissection. Neck Dissection is the surgical treatment of choice in lymphatic affection in HNSCC and should be performed even in early and clinically inappareant stages.(4)

While RND has been the treatment of choice for the past, focus in neck dissection has shifted to less invasive techniques in the past decade. $(5,6)$ In selective neck dissection (SND), many structures that are usually removed are preserved, including muscles, nerves and vascular structures. Moreover, one or several lymph node levels of the ipsi- or contralateral side are regularly spared. The assumption behind this approach is that the metastatic behavior of the primary tumor follows a predictable pattern, depending on where the tumor originated, and the treated regions are selected accordingly. The concept 
of predictable sequential regional spread in HNSCC has recently been confirmed for oral cavity scc by a comprehensive meta-analysis.(7) This makes neck dissection significantly less invasive and causes less short- and long-term side effects.

SND is to this day the surgical treatment of choice in patients with both likely nodal spread(8) as well as patients with clinically positive neck status(9). However, decision making is still difficult when it comes to selective neck dissection. Hence, we conducted a retrospective analysis of factors influencing the outcomes of neck dissection in a large collective at a tertiary referral center.

\section{Materials And Methods}

\section{Ethics}

The study at hand was conducted in accordance with the Declaration of Helsinki in its current form (seventh revision, 2013). The study was approved by the ethics committee at the University Medical Center of the Georg-August University Göttingen (Niedersachsen, Federal Republic of Germany) on January 10th 2017 under the File No. DOK_200_2016. All study participants consented in written form to the analysis of medical data before treatment at the study center.

\section{Data acquisition}

For data acquisition, the tumor database of the Department of Otorhinolaryngology of the University of Göttingen, established in 1986 by Wolfgang Steiner and coworkers, was used. This is a prospective Database in which all patients that had been primarily treated for HNSCC in the otolaryngology department and individual follow-ups were recorded. The database was used to extract patient information that included age, gender, tumor location, size, clinical TNM category, pathological TNM status, whether a neck dissection was performed, which levels were operated and the subsequent followup. Whenever the tumor database provided insufficient information on a specific case, individual patient files were consulted. TNM-Stages were given according to the 6th edition from 2002.

\section{Inclusion and exclusion criteria}

Patients with primary diagnosis of head and neck squamous cell carcinoma and surgical therapy in curative intention were considered for this analysis. Included were only patients with neck dissection as part of the initial therapy sequence. Exclusion criteria were cT4b stadium, distant metastasis when the tumor was initially diagnosed, patient that did not undergo surgical therapy of the tumor and patients that suffered from a synchronous secondary malignant disease. Also, patients that developed a local recurrence during follow-up were excluded from the analysis.

\section{Surgical approach}

All patients that were included in this study underwent transoral laser microsurgery (TLM) as primary treatment as has been established by Steiner and coworkers(10-12) with concomitant neck dissection. The dominance of TLM is particular for the local philosophy for management of HNSCC. Generally 
speaking, patients underwent SND of the ipsilateral levels II and III. If the primary tumor site was in the oral cavity, ipsilateral level I was included as well. In supraglottic laryngeal and hypopharyngeal tumor sites, levels II and III were treated on both sides. If tumor size was cT3 or cT4a of the oropharynx, hypopharynx or larynx, SND was performed in levels II, III and IV, respectively. If a cT3 or CT4a tumor was located in the oral cavity, levels I-IV were treated bilaterally. If any level showed suspicious lymph nodes, that regions was included in the SND as well. Patients that underwent SND in other levels than stated previously were still included in the analysis.

\section{Calculation of Overall survival and regional control rates}

When calculating overall survival (OS), death from any cause was counted as an event. When calculating regional control rates (RCR), tumor associated death or lymph node recurrence were counted as an event; patient that died from any cause apart from tumor associated death were considered as censored.

\section{Statistics}

Statistics were carried out using Project R for Mac (Build 3.4.1 for El Capitan, The R Project for Statistical Computing, http://www.r-project.org/) To estimate 5 and 10 year OS and RCR Kaplan-Meier-estimates were used. To assess the influence of individual parameters on OS or RCR, COX-Regressions were used. To detect interactions of the effects between tumor site and side, additional COX-Regressions were performed. If $p<0.05$, the results were considered to be statistically significant.

\section{Results}

Overall, 1608 patients were in the database. Out of these, 661 patients met inclusion criteria. Average age at time of diagnosis was $56.8 \pm 10.1$ years, with 558 (84.4\%) being male and 103 (15.6\%) being female. Mean follow-up time was $78.9 \pm 106.4$ months. Out of the 661 patients that were included, 67 patients (10.1\%) eventually had lymphatic recurrence of the tumor. 135 (20.4) patients had their primary tumor site in the oral cavity, $179(27.1 \%)$ in the oropharynx, $118(17.8 \%)$ in the hypopharynx and $229(34.6 \%)$ in the larynx. In terms of sides, 158 (23.9\%) were situated bilaterally, 23 (3.5\%) in the midline, 255 (38.6\%) on the right and $225(34.0 \%)$ on the left side. In terms of clinical lymph node category, $261(39.4 \%)$ patients were classified as inapparent/cN0, $111(16.8 \%)$ as N1, $246(37.2 \%)$ as N2 and $5(0.8 \%)$ as N3; in $38(5.7 \%)$ patients, there was no information on clinical lymph node status (cNx). After pathological examination, 302 (45.7\%) were classified as pN0, 119 (18.0\%) were classified as pN1, and 240 (36.3\%) as pN2. 105 (15.6\%) patients developed systemic metastasis during follow up, while 558 (84.4\%) did not. 291 (44.1\%) patients underwent adjuvant radio-(chemo-)therapy after initial surgical tumor therapy, while 370 (55.9\%) did not. (Table 1) Respective Kaplan-Meier-diagrams can be found in Fig. 1. 
Table 1

- Basic patient, tumor and surgery characteristics of all patients included in the study

\begin{tabular}{|c|c|}
\hline Characteristic & No. of Patients $(n=661)$ \\
\hline Age (years) & $56.8 \pm 10.1[15.7-91.6]$ \\
\hline Gender (male/female) & $558(84.4 \%) / 103$ (15.6\%) \\
\hline Follow up (months) & $78,9 \pm 106.4$ [0.3-263.3] \\
\hline \multicolumn{2}{|l|}{ Origin } \\
\hline Tumor Origin: Oral cavity & $135(20.4 \%)$ \\
\hline Tumor Origin: Oropharynx & $179(27.1 \%)$ \\
\hline Tumor Origin: Hypopharynx & $118(17.8 \%)$ \\
\hline Tumor Origin: Larynx & $229(34.6 \%)$ \\
\hline \multicolumn{2}{|l|}{ Side } \\
\hline Tumor side: bilateral & $158(23.9 \%)$ \\
\hline Tumor side: midline & $23(3.5 \%)$ \\
\hline Tumor side: right & $255(38.6 \%)$ \\
\hline Tumor side: left & $225(34.0 \%)$ \\
\hline \multicolumn{2}{|l|}{ Tumor Stage } \\
\hline pT1 & $86(13.0 \%)$ \\
\hline pT2 & $208(31.5 \%)$ \\
\hline pT3 & $239(36.2 \%)$ \\
\hline pT4 & $128(19.4 \%)$ \\
\hline \multicolumn{2}{|l|}{ Lymph Node Status } \\
\hline cNO & $261(39.4 \%)$ \\
\hline cN1 & $111(16.8 \%)$ \\
\hline $\mathrm{cN} 2$ & $246(37.2 \%)$ \\
\hline cN3 & $5(0.8 \%)$ \\
\hline $\mathrm{cNx}$ & $38(5.7 \%)$ \\
\hline pNO & $302(45.7 \%)$ \\
\hline pN1 & $119(18.0 \%)$ \\
\hline
\end{tabular}




\begin{tabular}{|ll|}
\hline Characteristic & No. of Patients ( $\mathbf{n}=661)$ \\
\hline pN2 & $240(36.3 \%)$ \\
\hline Development of distant metastasis during follow-up \\
\hline M0 & $558(84.4 \%)$ \\
\hline M1 & $103(15.6 \%)$ \\
\hline Postoperative (chemo-)radiotherapy & \\
\hline No adjuvant therapy & $370(55.9 \%)$ \\
\hline Postoperative (chemo-)radiotherapy & $291(44.1 \%)$ \\
\hline Levels Treated in Neck Dissection & \\
\hline Ipsilateral ND & $644(97.4 \%)$ \\
\hline Level I ispilateral & $120(18.2 \%)$ \\
\hline Level II ispilateral & $613(92.7 \%)$ \\
\hline Level III ispilateral & $605(91.5 \%)$ \\
\hline Level IV ispilateral & $140(21.2 \%)$ \\
\hline Level V ispilateral & $26(3.9 \%)$ \\
\hline Contralateral ND & $319(48.3 \%)$ \\
\hline Level I contralateral & $54(8.2 \%)$ \\
\hline Level II contralateral & $313(47.4 \%)$ \\
\hline Level III contralateral & $309(46.7 \%)$ \\
\hline Level IV contralateral & $55(8.3 \%)$ \\
\hline Level V contralateral & $7(1.1 \%)$ \\
\hline
\end{tabular}

Out of these patients, 644 (97.4\%) underwent ispiateral and $319(48.3 \%)$ underwent contralateral neck dissection. On the ipsilateral side, Level I was operated on in 120 (18.2\%) patients, Level II in 613 (92.7\%), Level III in 605 (91.5\%), Level IV in $140(21.2 \%)$ and Level V in $26(3.9 \%)$ patients. On the contralateral side, Level I was operated in 54 (8.2\%) patients, Level II in 313 (47.4\%), Level III in 398 (46.7\%), Level IV in $55(8.3 \%)$ and Level $\mathrm{V}$ in $7(1.1 \%)$ patients (Table 1$).$

The exact comparisons between the groups in terms of OS and RCR can be found in Table 2. Univariate testing found significant differences in RCR between hypopharynx and larynx as well as hypopharynx and oropharynx, showing lower hazard of regional recurrence for primaries located in the oropharynx (HR 0.6 [0.4-1.0]) and larynx (HR 0.4 [0.2-0.7]). In terms of OS, only the difference between larynx and hypopharynx was significant, demonstrating a better prognosis for laryngeal cancer (HR 0.4 [0.2-0.7]). 
However, multivariate testing showed a significant influence of the tumor site on both RCR and OS. In terms of pathological tumor category, there was no uni- or multivariate influence on RCR. In terms of OS, pT4a compared to all other categories showed significant differences in univariate testing. Multivariate testing showed a significant influence of pathological tumor category on OS. 
Table 2

- Univariate and multivariate testing of tumor and surgery characteristics and their respecitve influence on OS and RCR

\begin{tabular}{|c|c|c|c|c|c|c|}
\hline Stage & $\begin{array}{l}\text { Hazard } \\
\text { Ratio }\end{array}$ & p & p & $\begin{array}{l}\text { Hazard } \\
\text { Ratio }\end{array}$ & p (univariate) & p \\
\hline & \multicolumn{3}{|c|}{ Regional Control Rate } & \multicolumn{3}{|c|}{ Overall Survival } \\
\hline Tumor Origin & & $<0.01$ & $<0.01$ & & 0.02 & 0.01 \\
\hline $\begin{array}{l}\text { Larynx vs. } \\
\text { Hypopharynx }\end{array}$ & $\begin{array}{l}0.4[0.2- \\
0.7]\end{array}$ & $<0.01$ & & $\begin{array}{l}0.4 \\
{[0.2-} \\
0.7]\end{array}$ & $<0.01$ & \\
\hline $\begin{array}{l}\text { Oral Cavity vs. } \\
\text { Hypopharynx }\end{array}$ & $\begin{array}{l}0.6[0.4- \\
1.1]\end{array}$ & 0.12 & & $\begin{array}{l}0.6 \\
{[0.4-} \\
1.1]\end{array}$ & 0.12 & \\
\hline $\begin{array}{l}\text { Oropharynx vs. } \\
\text { Hypopharynx }\end{array}$ & $\begin{array}{l}0.6[0.4- \\
1.0]\end{array}$ & 0.05 & & $\begin{array}{l}0.7 \\
{[0.4-} \\
1.2]\end{array}$ & 0.16 & \\
\hline Oral Cavity vs. Larynx & $\begin{array}{l}1.7[1.0- \\
3.1]\end{array}$ & 0.06 & & $\begin{array}{l}1.5 \\
{[0.9-} \\
2.8]\end{array}$ & 0.15 & \\
\hline $\begin{array}{l}\text { Oropharynx vs. Oral } \\
\text { Cavity }\end{array}$ & $\begin{array}{l}0.9[0.5- \\
1.6]\end{array}$ & 0.78 & & $\begin{array}{l}1.1 \\
{[0.6-} \\
1.9]\end{array}$ & 0.80 & \\
\hline $\begin{array}{l}\text { Oropharynx vs. } \\
\text { Larynx }\end{array}$ & $\begin{array}{l}1.5[0.6- \\
1.5]\end{array}$ & 0.12 & & $\begin{array}{l}1.6 \\
{[0.9-} \\
2.8]\end{array}$ & 0.08 & \\
\hline $\begin{array}{l}\text { Pathological Tumor } \\
\text { Category }\end{array}$ & & 0.13 & 0.07 & & $<0.01$ & $<0.01$ \\
\hline pT2 vs. pT1 & $\begin{array}{l}1.6[0.8- \\
3.2]\end{array}$ & & & $\begin{array}{l}1.7 \\
{[0.8-} \\
3.6]\end{array}$ & 0.16 & \\
\hline pT3 vs. pT1 & $\begin{array}{l}1.1[0.5- \\
2.1]\end{array}$ & & & $\begin{array}{l}1.2 \\
{[0.6-} \\
2.7]\end{array}$ & 0.57 & \\
\hline pT4 vs. pT1 & $\begin{array}{l}1.7[0.8- \\
3.4]\end{array}$ & & & $\begin{array}{l}3.1 \\
{[1.5-} \\
6.5]\end{array}$ & $<0.01$ & \\
\hline pT3 vs. pT2 & $\begin{array}{l}0.6[0.4- \\
1.0]\end{array}$ & & & $\begin{array}{l}0.7 \\
{[0.4-} \\
1.2]\end{array}$ & 0.25 & \\
\hline pT4 vs. pT3 & $\begin{array}{l}0.6[0.4- \\
1.0]\end{array}$ & & & $\begin{array}{l}2.5 \\
{[1.5-} \\
4.2]\end{array}$ & $<0.01$ & \\
\hline
\end{tabular}




\begin{tabular}{|c|c|c|c|c|c|c|}
\hline Stage & $\begin{array}{l}\text { Hazard } \\
\text { Ratio }\end{array}$ & (univariate) & (multiple) & $\begin{array}{l}\text { Hazard } \\
\text { Ratio }\end{array}$ & p (univariate) & P \\
\hline pT4 vs. pT2 & $\begin{array}{l}1.0[0.6- \\
1.7]\end{array}$ & & & $\begin{array}{l}1.8 \\
{[1.1-} \\
3.0]\end{array}$ & 0.01 & \\
\hline $\begin{array}{l}\text { Clinical Lymph Node } \\
\text { Category }\end{array}$ & & $<0.01$ & $<0.01$ & & $<0.01$ & $<0.01$ \\
\hline cN1 vs. cN0 & $\begin{array}{l}1.9[1.1- \\
3.4]\end{array}$ & 0.03 & & $\begin{array}{l}1.8 \\
{[1.0-} \\
3.4]\end{array}$ & 0.06 & \\
\hline cN2 vs. cN0 & $\begin{array}{l}2.4[1.5- \\
3.8]\end{array}$ & $<0.01$ & & $\begin{array}{l}3.0 \\
{[1.8-} \\
4.9]\end{array}$ & $<0.01$ & \\
\hline cN3 vs. cNO & $\begin{array}{l}5.4[1.3- \\
22.7]\end{array}$ & 0.02 & & $\begin{array}{l}9.4 \\
{[2.2-} \\
40.0]\end{array}$ & $<0.01$ & \\
\hline cN2 vs. cN1 & $\begin{array}{l}1.3[0.7- \\
2.1]\end{array}$ & 0.40 & & $\begin{array}{l}1.6 \\
{[0.9-} \\
2.8]\end{array}$ & 0.09 & \\
\hline cN3 vs. cN1 & $\begin{array}{l}2.6[0.6- \\
11.2]\end{array}$ & 0.20 & & $\begin{array}{l}4.9 \\
{[1.1-} \\
22.2]\end{array}$ & 0.04 & \\
\hline cN3 vs. cN2 & $\begin{array}{l}2.3[0.6- \\
9.6]\end{array}$ & 0.24 & & $\begin{array}{l}3.0 \\
{[0.7-} \\
12.3]\end{array}$ & 0.13 & \\
\hline $\begin{array}{l}\text { Pathological Lymph } \\
\text { Node Category }\end{array}$ & & $<0.01$ & $<0.01$ & & $<0.01$ & $<0.01$ \\
\hline pN1 vs. pN0 & $\begin{array}{l}1.9[1.0- \\
3.5]^{[1.0-}\end{array}$ & 0.05 & & $\begin{array}{l}2.6 \\
{[1.4-} \\
5.0]\end{array}$ & $<0.01$ & \\
\hline pN2 vs. pN0 & $\begin{array}{l}4.0[2.5- \\
6.4]\end{array}$ & $<0.01$ & & $\begin{array}{l}5.2 \\
{[3.1-} \\
8.7]\end{array}$ & $<0.01$ & \\
\hline pN2 vs. pN1 & $\begin{array}{l}2.1[1.3- \\
3.7]\end{array}$ & $<0.01$ & & $\begin{array}{l}2.0 \\
{[1.2-} \\
3.3]\end{array}$ & 0.01 & \\
\hline $\begin{array}{l}\text { Development of } \\
\text { distant metastasis }\end{array}$ & $\begin{array}{l}6.6, \\
{[4.5-9.6]}\end{array}$ & $<0.01$ & 0.25 & $\begin{array}{l}9.8 \\
{[6.5-} \\
14.6]\end{array}$ & $<0.01$ & $<0.01$ \\
\hline $\begin{array}{l}\text { Postoperative } \\
\text { (Chemo-) } \\
\text { radiation }\end{array}$ & $\begin{array}{l}0.9 \\
{[0.6-1.3]}\end{array}$ & 0.51 & $<0.01$ & $\begin{array}{l}0.5 \\
{[0.3-} \\
0.8]\end{array}$ & $<0.01$ & 0.13 \\
\hline
\end{tabular}




\begin{tabular}{|c|c|c|c|c|c|c|}
\hline Stage & $\begin{array}{l}\text { Hazard } \\
\text { Ratio }\end{array}$ & p (univariate) & p & $\begin{array}{l}\text { Hazard } \\
\text { Ratio }\end{array}$ & p & p \\
\hline $\begin{array}{l}\text { Neck Dissection } \\
\text { ipsilateral }\end{array}$ & $\begin{array}{l}0.7[0.3- \\
2.0]\end{array}$ & 0.56 & 0.37 & $\begin{array}{l}0.9 \\
{[0.3-} \\
3.0]\end{array}$ & 0.93 & 0.64 \\
\hline Level I ipsilateral & $\begin{array}{l}1.3[0.8- \\
2.0]\end{array}$ & 0.30 & 0.25 & $\begin{array}{l}1.0 \\
{[0.6-} \\
1.7]\end{array}$ & 0.96 & 0.68 \\
\hline Level II ipsilateral & $\begin{array}{l}0.5[0.3- \\
0.9]\end{array}$ & 0.01 & 0.72 & $\begin{array}{l}0.5 \\
{[0.3-} \\
0.9]\end{array}$ & 0.02 & 0.83 \\
\hline Level III ipsilateral & $\begin{array}{l}0.6[0.3- \\
1.1]\end{array}$ & 0.07 & 0.18 & $\begin{array}{l}0.6 \\
{[0.3-} \\
1.0]\end{array}$ & 0.05 & 0.96 \\
\hline Level IV ipsilateral & $\begin{array}{l}1.1[0.7- \\
1.8]\end{array}$ & 0.62 & 0.44 & $\begin{array}{l}1.2 \\
{[0.8-} \\
1.9]\end{array}$ & 0.42 & 0.61 \\
\hline $\begin{array}{l}\text { Level V } \\
\text { ipsilateral }\end{array}$ & $\begin{array}{l}0.8[0.2- \\
2.5]\end{array}$ & 0.68 & 0.44 & $\begin{array}{l}0.7 \\
{[0.2-} \\
2.9]\end{array}$ & 0.63 & 0.27 \\
\hline $\begin{array}{l}\text { Neck Dissection } \\
\text { contralateral }\end{array}$ & $\begin{array}{l}1.0[0.7- \\
1.4]^{[0 .}\end{array}$ & 0.93 & 0.40 & $\begin{array}{l}1.3 \\
{[0.9-} \\
2.0]\end{array}$ & 0.14 & 0.79 \\
\hline Level I contralateral & $\begin{array}{l}1.6[0.9- \\
2.9]\end{array}$ & 0.10 & 0.17 & $\begin{array}{l}1.8[ \\
1.0- \\
3.3]\end{array}$ & 0.04 & 0.07 \\
\hline Level II contralateral & $\begin{array}{l}1.0[0.7- \\
1.4]\end{array}$ & 0.89 & 0.88 & $\begin{array}{l}1.3 \\
{[0.9-} \\
1.9]\end{array}$ & 0.23 & 0.21 \\
\hline Level III contralateral & $\begin{array}{l}1.0[0.7- \\
1.4]\end{array}$ & 0.96 & 0.70 & $\begin{array}{l}1.3 \\
{[0.9-} \\
1.9]\end{array}$ & 0.20 & 0.83 \\
\hline Level IV contralateral & $\begin{array}{l}1.2[0.7- \\
2.4]\end{array}$ & 0.50 & 0.48 & $\begin{array}{l}1.6 \\
{[0.8-} \\
2.9]\end{array}$ & 0.16 & 0.86 \\
\hline $\begin{array}{l}\text { Level V } \\
\text { contralateral }\end{array}$ & $\begin{array}{l}0.0[0.0- \\
\infty]\end{array}$ & 0.15 & 0.23 & $\begin{array}{l}0.0[0- \\
\infty]\end{array}$ & 0.20 & 0.30 \\
\hline
\end{tabular}

Clinical lymph node status showed a significant effect on RCR in any stage compared with cNO in univariate analysis, demonstrating a higher hazard ratio of regional recurrence in $\mathrm{cN}+$ disease. For overall survival this was only the case for $\mathrm{CN} 2$ and compared to $\mathrm{cN} 1$. Multivariate testing showed a significant influence both for RCR and OS (Table 2). 
Pathological lymph node status showed a significant influence on RCR and OS both in univariate and multivariate testing. Development of distant metastasis showed a significant influence on OS both in uniand multivariate testing and a significant influence on RCR in univariate testing. Adjuvant (chemo)radiotherapy showed a significant impact on RCR in multivariate and a significant impact on OS in univariate testing. Treated levels during SND showed a significant influence on RCR if ipsilateral Level II was treated in univariate testing. In terms of OS, ipsilateral regions II and III as well as contralateral level I showed a significant influence in univariate testing.

To test whether the observed impact on OS and RCR was dependent on the tumor origin, COX-regression models were fitted that considered the interactions of the tumor origin. These models found a significant influence of surgical treatment of levels I and V ipsilateral and level III contralateral on OS. None of the fitted models revealed a significant influence of any level treated on RCR. (Table 3) Significant findings in these levels indicated that treatment or omission of treatment of these regions may influence overall survival dependent of tumor origin. 
Table 3

- COX-Regression Models of Operated Regions dependent and independent of tumor origin

\begin{tabular}{|lll|}
\hline & $\begin{array}{l}\text { Overall Survival } \\
\text { p (multiple) }\end{array}$ & $\begin{array}{l}\text { Regional Control Rates } \\
\text { p (multiple) }\end{array}$ \\
\hline Region & $\mathbf{0 . 0 2}$ & $<0.01$ \\
\hline Level I Ipsilateral & 0.93 & 0.36 \\
\hline Level II Ipsilateral & 0.08 & 0.04 \\
\hline Level III Ipsilateral & 0.69 & 0.10 \\
\hline Level IV Ipsilateral & 0.58 & 0.79 \\
\hline Level V Ipsilateral & 0.54 & 0.68 \\
\hline Level I Contralateral & 0.02 & 0.25 \\
\hline Level II Contralateral & 0.39 & 0.80 \\
\hline Level III Contralateral & 0.65 & 0.87 \\
\hline Level IV Contralateral & 0.45 & 0.50 \\
\hline Level V Contralateral & 0.20 & 0.16 \\
\hline Models with Tumor Origin Interaction & \\
\hline Level I Ipsilateral & $\mathbf{0 . 0 3}$ & 0.81 \\
\hline Level II Ipsilateral & 0.19 & 0.07 \\
\hline Level III Ipsilateral & 0.43 & 1.00 \\
\hline Level IV Ipsilateral & 0.47 & 0.95 \\
\hline Level V Ipsilateral & $\mathbf{0 . 0 2}$ & 0.16 \\
\hline Level I Contralateral & 0.66 & 0.14 \\
\hline Level II Contralateral & 0.98 & 0.13 \\
\hline Level III Contralateral & $<0.01$ & 0.60 \\
\hline Level IV Contralateral & 0.00 \\
\hline Level V Contralateral & 1.00 & 0.00 \\
\hline
\end{tabular}

Subsequently, we fitted COX-regression models for each tumor region. (Table 4) Treatment of level V ipsilateral or level III contralateral showed no significant influence on OS in any tumor origin. Treatment of level I ipsilateral showed a significant influence on OS when the tumor originated in the oral cavity. The 
hazard ratio calculated was 0.4 with a confidence interval of $0.2-0.9$. This indicated a favorable effect of SND in level I in HNSCC of the oral cavity.

Table 4

- Influence of Neck Dissection Levels for each Tumor Origin

\begin{tabular}{|lllll|}
\hline Parameter & \multicolumn{2}{l}{ Region } & & \\
\cline { 2 - 5 } & Hypopharynx & Larynx & Oral Cavity & Oropharynx \\
\hline Level I Ispilateral & $4.0[0.9-17.2]$ & $3.7[0.5-27.3]$ & $\mathbf{0 . 4}[0.2-0.9]$ & $1.9[0.8-4.7]$ \\
& $p=0.06$ & $p=0.21$ & $p=0.02$ & $p=0.17$ \\
Level V Ipsilateral & $0.0[0.0-\infty]$ & $0.0[0.0-\infty]$ & $0.0[0.0-\infty]$ & $3.0[0.7-13.1]$ \\
& $p=0.16$ & $p=0.24$ & $p=0.26$ & $p=0.14$ \\
\hline Level III Contralateral & $1.7[0.7-3.7]$ & $1.2[0.5-2.8]$ & $1.7[0.7-4.0]$ & $1.4[0.7-2.9]$ \\
& $p=0.22$ & $p=0.68$ & $p=0.21$ & $p=0.38$ \\
\hline
\end{tabular}

\section{Discussion}

\section{Synopsis of key findings}

This retrospective analysis of date basing on prospective documentation of consecutive cases of head and neck cancer identified factors for regional failure and general outcome. Firstly, we found that the tumor site has both a significant effect on regional control rates as well as overall survival. Moreover, both clinical and pathological lymph node status shows a significant impact on both overall survival and regional control rates. Tumor size, as indicated by the pT-categories, showed a significant impact on OS but not RCR. Finally, the value of ipsilateral dissection of level I in oral cavity cancer was emphasized.

\section{Strengths and Limitations}

A strength of this work is a high number of 661 cases and a considerably long follow-up-time of $78.9 \pm$ 106.4 months. Other recent studies report 84 to 123 patients (13-15)with 12 to 30 months of follow-up. $(13,15)$

However, due to the at least partially retrospective nature of this analysis, this study is subject to probably systematic lack of data and various kinds of bias. Clinical decisions, for example regarding the inclusion or omission of a particular neck level into a neck dissection might have been due to factors that cannot be deducted from the available data in retrospect.

\section{Comparison to other studies}

It has been established that SND is the appropriate treatment for regional spread in HNSCC. D'Cruz and colleagues found in a randomized, prospective study that elective SND in early HNSCC of the oral cavity 
is superior to a wait-and see approach and subsequent SND in the case of positive lymph nodes.(16)An influence of tumor site on regional control and overall survival is mainly due to the fact that laryngeal and oropharyngeal HNSCC are showing a significant impact on OS and RCR. This is not surprising as hypopharyngeal carcinomas have a very poor overall prognosis; commonly they are diagnosed in a late stage and with advanced nodal stage.(17) Moreover, they often show a tendency for more dedifferentiated carcinomas and occult cervical metastasis.(18) These factors make surgical management of hypopharyngeal carcinoma significantly more demanding, with a distinct possibility of occult tumor cells remaining on site, impairing both RCR as well as OS.A heavy influence of clinical and pathological lymph node status is not surprising, given that the greater the load of tumor cells in the neck, the greater the probability of cells not being reached by surgery and eventually creating the foundation for recurrence of cancer. Subsequently, this observation is very much in line with literature addressing this topic: Layland and colleagues found in over 3.800 patients that advanced neck stages are associated with poorer OS in all tumor sites.(18) Ambrosch and colleague found in a very similar collective to that at hand that advanced nodal stage as well as extracapsular extension are associated with a greater probability for regional recurrences.(19)While the impact of tumor size on OS is not surprising and has been evaluated in large-scale studies,(20) the missing correlation between tumor size and RCR in our sample is somewhat surprising. We believe that this observation may be explained by the (relatively) effective removal of the primary tumor by TLM.(21-23) When considering the individual neck dissection levels that were included during surgery, we found in the models that included an interaction with the tumor site that levels I and V ipsilaterally as well as level III contralaterally showed an influence on overall survival upon closer examination. When correcting those models for the tumor site, we only found a significant impact on overall survival on ipsilateral neck dissection in contralateral level I in HNSCC of the oral cavity. Fittingly, the respective level has been included in the prospective study by D'Cruz and colleagues that found elective neck dissection to be superior to a wait-and-see approach.(16) The recommendation for elective and therapeutic surgical treatment of level I in oral cavity SCC has already been given in a comprehensive clinical practice guideline.(24) While those models that did correct for tumor origin did not indicate a statistically significant influence on OS, it is our conviction that inclusion of these levels in primary SND may still be beficiary and should be considered by surgeons. Fittingly, Frohwitter and colleagues found that affection of ipsilateral levels IV and V considerably decreases overall survival in HNSCC of the oral cavity.(14)

\section{Conclusion}

In conclusion, we found clear evidence that SND is effective both in preventing nodal relapse in clinically inapparent necks as well as treating clinically positive necks. The study at hand is - to the best of the authors knowledge - the largest study to comprehensively analyze the treated levels in SND dependent on tumor size and origin. Consequently, we found evidence that when performing surgery on the neck on HNSCC of the oral cavity, dissection of ispilateral level I should be included.

\section{Abbreviations}


HNSCC Head and Neck Squamous Cell Carcinoma

OS Overall Survival

RCR Regional Control Rate

RND Radical Neck Dissection

SND Selective Neck Dissection

TLM Transoral Laser Microsurgery

\section{Declarations}

\section{Ethics approval and consent to participate}

The study at hand was conducted in accordance with the Declaration of Helsinki in its current form (seventh revision, 2013). The study was approved by the ethics committee at the University Medical Center of the Georg-August University Göttingen (Niedersachsen, Federal Republic of Germany) on January 10th 2017 under the File No. DOK_200_2016. All study participants consented in written form to the analysis of medical data before treatment at the study center.

\section{Dataset}

The authors of this manuscript declare that the data at hand have not been published, submitted or used in any other manuscript elsewhere.

\section{Consent for publication}

Not Applicable.

\section{Availability of data and materials}

The dataset generated and analysed during the current study is not publicly available, since the local ethics committee explicitly discouraged the publication of individual data in its statement due to data privacy. The corresponding author will provide an anonymized dataset on reasonable request.

\section{Competing interests}

The authors declare no relevant conflict of interest.

\section{Funding}

This work was partially funded by a grant to Fl by the German Federal Ministry of Education and Health (BMBF) (grant number 01 EO 0901). 


\section{Authors' contributions}

Study concept: FI

Study design: $M B, F H, M C$

Data acquisition: NZ, BGW, JLS

Quality control of data and algorithms: MB, SF, BGW, FI

Data Analysis and Interpretation: MB, SF, BGW, FH, FI, JLS

Statistical analysis: SF

Manuscript Preparation; MB, NZ, JLS

Manuscript editing: $\mathrm{BGW}, \mathrm{FH}, \mathrm{FI}$

Manuscript Review: SF, MC

All authors have read and approved the manuscript.

\section{Acknowledgements}

The authors are indebted to Professor Wolfgang Steiner for his inspiring work in head and neck surgery and for clinical, surgical, as well as scientific guidance. The authors want to thank Brigitte Bruhse for excellent support in the documentation of tumor cases throughout many years.

\section{References}

1. Mamelle G, Pampurik J, Luboinski B, Lancar R, Lusinchi A, Bosq J. Lymph node prognostic factors in head and neck squamous cell carcinomas. Am J Surg. 1994 Nov;168(5):494-8.

2. Cerezo L, Millán I, Torre A, Aragón G, Otero J. Prognostic factors for survival and tumor control in cervical lymph node metastases from head and neck cancer. A multivariate study of 492 cases. Cancer. 1992 Mar;69(5):1224-34.

3. Robbins KT, Medina J, Ferlito A. Adding clarity to the historical evolution of the selective neck dissection. Vol. 41, Head \& neck. United States; 2019. p. 1542-4.

4. Oh LJ, Phan K, Kim SW, Low TH, Gupta R, Clark JR. Elective neck dissection versus observation for early-stage oral squamous cell carcinoma: Systematic review and meta-analysis. Oral Oncol. 2020 Jun;105:104661.

5. Ferlito A, Rinaldo A. Is radical neck dissection a current option for neck disease? Vol. 118, The Laryngoscope. United States; 2008. p. 1717-8. 
6. Hamoir M, Silver CE, Schmitz S, Takes RP, Rinaldo A, Rodrigo JP, et al. Radical neck dissection: is it still indicated? Vol. 270, European archives of oto-rhino-laryngology: official journal of the European Federation of Oto-Rhino-Laryngological Societies (EUFOS) : affiliated with the German Society for Oto-Rhino-Laryngology - Head and Neck Surgery. Germany; 2013. p. 1-4.

7. Warshavsky A, Rosen R, Nard-Carmel N, Abu-Ghanem S, Oestreicher-Kedem Y, Abergel A, et al. Assessment of the Rate of Skip Metastasis to Neck Level IV in Patients With Clinically Node-Negative Neck Oral Cavity Squamous Cell Carcinoma: A Systematic Review and Meta-analysis. JAMA Otolaryngol Head Neck Surg. 2019 Jun;145(6):542-8.

8. Coskun HH, Medina JE, Robbins KT, Silver CE, Strojan P, Teymoortash A, et al. Current philosophy in the surgical management of neck metastases for head and neck squamous cell carcinoma. Head Neck. 2015 Jun;37(6):915-26.

9. Givi B, Linkov G, Ganly I, Patel SG, Wong RJ, Singh B, et al. Selective neck dissection in node-positive squamous cell carcinoma of the head and neck. Otolaryngol neck Surg Off J Am Acad Otolaryngol Neck Surg. 2012 Oct;147(4):707-15.

10. Steiner W. [Laser surgery in the ENT field (laser surgery for the treatment of malignant tumors of the upper aerodigestive tract)]. Arch oto-rhino-laryngology Suppl = Arch fur Ohren-, Nasen- und Kehlkopfheilkunde Suppl. 1987;2:8-18.

11. Steiner W. Results of curative laser microsurgery of laryngeal carcinomas. Am J Otolaryngol. 1993;14(2):116-21.

12. Steiner W. Experience in endoscopic laser surgery of malignant tumours of the upper aero-digestive tract. Adv Otorhinolaryngol [Internet]. 1988 [cited 2016 Jul 18];39:135-44. Available from: http://www.ncbi.nlm.nih.gov/pubmed/2455969

13. Last AS, Pipkorn P, Chen S, Kallogjeri D, Zenga J, Rich JT, et al. Risk and Rate of Occult Contralateral Nodal Disease in Surgically Treated Patients With Human Papillomavirus-Related Squamous Cell Carcinoma of the Base of the Tongue. JAMA Otolaryngol Head Neck Surg. 2020 Jan;146(1):50-6.

14. Frohwitter G, Röckl J, Rau A, Wolff K-D, Kesting MR, Koerdt S. Evaluation of neck dissection with frozen section biopsy - Management of levels IV and V. J cranio-maxillo-facial Surg Off Publ Eur Assoc Cranio-Maxillo-Facial Surg. 2019 Dec;47(12):1963-7.

15. Wang D, Yu S, Zhai L, Xu J, Li B. Patterns of regional lymph node failure of locally advanced hypopharyngeal squamous cell carcinoma after first-line treatment with surgery and/or intensitymodulated radiotherapy. BMC Cancer. 2020 Apr;20(1):283.

16. D'Cruz AK, Vaish R, Kapre N, Dandekar M, Gupta S, Hawaldar R, et al. Elective versus Therapeutic Neck Dissection in Node-Negative Oral Cancer. N Engl J Med. 2015 Aug;373(6):521-9.

17. Visini M, Giger R, Shelan M, Elicin O, Anschuetz L. Predicting Factors for Oncological and Functional Outcome in Hypopharyngeal Cancer. Laryngoscope. 2020 Oct;

18. Layland MK, Sessions DG, Lenox J. The influence of lymph node metastasis in the treatment of squamous cell carcinoma of the oral cavity, oropharynx, larynx, and hypopharynx: N0 versus $\mathrm{N}+$. Laryngoscope. 2005 Apr;115(4):629-39. 
19. Ambrosch P, Kron M, Pradier O, Steiner W. Efficacy of selective neck dissection: a review of 503 cases of elective and therapeutic treatment of the neck in squamous cell carcinoma of the upper aerodigestive tract. Otolaryngol neck Surg Off J Am Acad Otolaryngol Neck Surg. 2001 Feb;124(2):180-7.

20. Xing Y, Zhang J, Lin H, Gold KA, Sturgis EM, Garden AS, et al. Relation between the level of lymph node metastasis and survival in locally advanced head and neck squamous cell carcinoma. Cancer. 2016 Feb;122(4):534-45.

21. Weiss BG, Ihler F, Anczykowski MZ, Bertlich M, Kitz J, Steiner W, et al. Transoral laser microsurgery for treatment of oropharyngeal cancer in 368 patients. Head Neck. 2019;41(9).

22. Weiss BG, Ihler F, Wolff HA, Schneider S, Canis M, Steiner W, et al. Transoral laser microsurgery for treatment for hypopharyngeal cancer in 211 patients. Head Neck. 2017 Aug;

23. Canis M, Martin A, Ihler F, Wolff HA, Kron M, Matthias C, et al. Transoral laser microsurgery in treatment of pT2 and pT3 glottic laryngeal squamous cell carcinoma - results of 391 patients. Head Neck. 2014 Jun;36(6):859-66.

24. Koyfman SA, Ismaila N, Crook D, D'Cruz A, Rodriguez CP, Sher DJ, et al. Management of the Neck in Squamous Cell Carcinoma of the Oral Cavity and Oropharynx: ASCO Clinical Practice Guideline. J Clin Oncol Off J Am Soc Clin Oncol. 2019 Jul;37(20):1753-74.

\section{Figures}



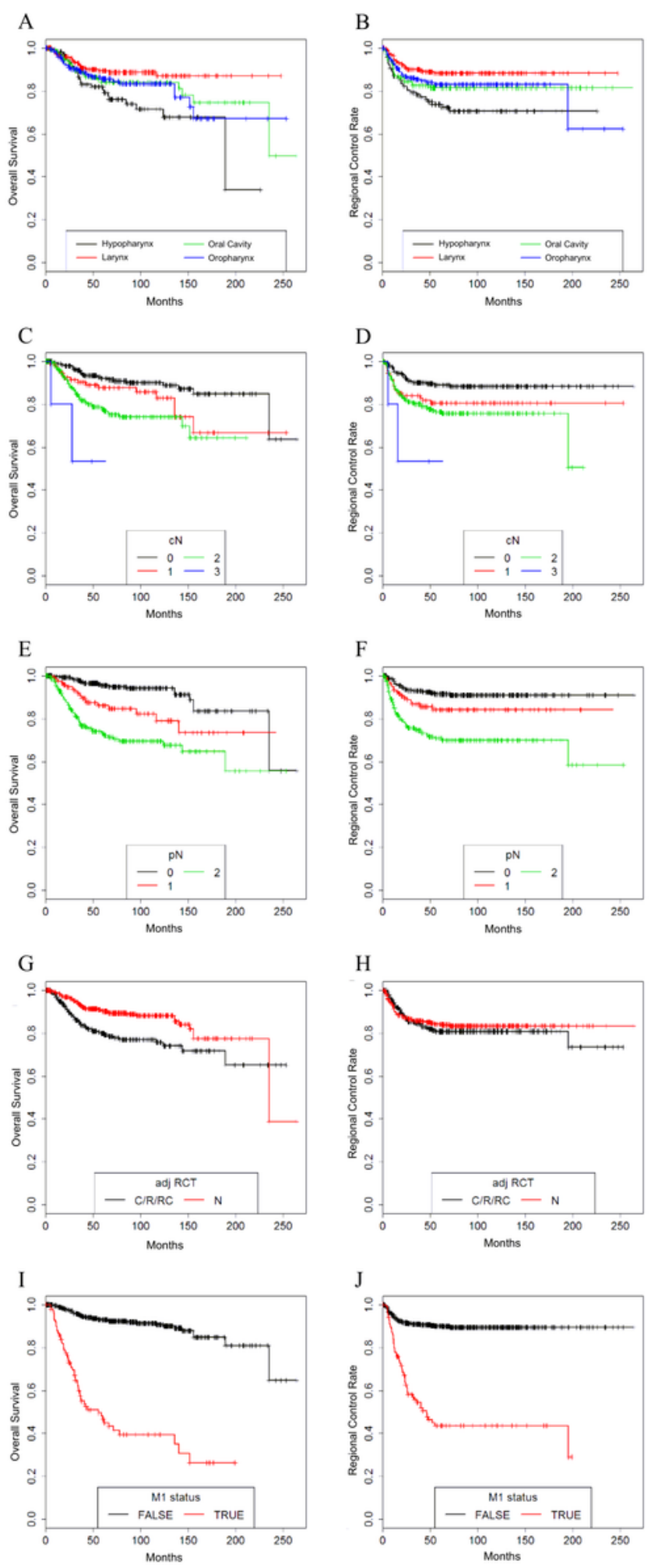

\section{Figure 1}

Kaplan Meier Curves: (A) Overall Survival of all patients dependent of tumor site (B) Regional control rate of all patients dependent of tumor site (C) Overall survival of all patients dependent on clinical lymph node category (D) Regional control rate of all patients dependent on clinical lymph node category (E) Overall survival of all patients dependent on pathological lymph node category (F) Regional Control Rate of all patients dependent on pathological lymph node stage $(G)$ Overall survival of all patients dependent 
on whether they underwent postoperative radio-(chemo-)therapy $(\mathrm{H})$ Regional control rate of all patients dependent on whether they underwent postoperative Radio-(chemo-)therapy (I) Overall survival of all patients dependent on whether they developed distant metastasis $(\mathrm{J})$ Regional control rate of all patients dependent on whether they developed distant metastasis 